\title{
Study of Liver Biopsy in Chronic Liver Diseases
}

\author{
Pavan Kulkarni ${ }^{1}$ and Sheela Devi $C S^{2 *}$ \\ 'Dept of Pathology, S Nijalingappa Medical College, Bagalkot, Karnataka, India \\ ${ }^{2}$ Dept of Pathology, JSS Medical College, Mysuru, Karnataka, India
}

\begin{abstract}
Background: Chronic liver disease (CLD)represents liver disorders of varying causes and severity in which hepatic inflammation and necrosis continue for at least 6 months. The treatment of cause leads to regression of fibrosis and parenchymal recovery. Liver biopsy is often used to establish the diagnosis, assess the severity of disease in CLD and its role is evolving with advances in medical technology.

The objective was to study the histopathological pattern of injury in patients with CLD and thereby establish a possible etiologic diagnosis in correlation with clinical, biochemical and serologic findings.

Methods: Thirty five cases of CLD with histopathological features of necroinflammation/fibrosis were studied for a period of five years. Along with demographics and laboratory parameters, sections were studied for the pattern and degree of injury.Grading and staging were done using standard systems.

Results: Nonalcoholic fatty liver disease $(31.42 \%)$ and alcoholic liver disease $(25.71 \%)$ were the most common causes followed by viral hepatitis (11.42\%) and drug induced liver injury (8.58\%). One case each of autoimmune hepatitis and primary biliary cirrhosis were seen. A definitive diagnosis was not possible in six patients, and only a probable etiology was considered.

Conclusion: The natural history of CLD is changing and is important to establish an etiological diagnosis. Despite the advances in diagnostic techniques, liver biopsy remains a valuable tool to establish the etiology and traditional descriptive reports still hold importance for the treatment and prognosis.However, it remains challenging and should be interpreted in the setting of clinical, biochemical, serological and radiological findings.
\end{abstract}

\section{Keywords: Chronic Liver Diseases, Histopathology, Grading, Staging, Etiology}

\section{Introduction}

Chronic liver disease (CLD) is the most common route to hepatic failure. Clinicopathological observations have shown that treatment or removal of causative agent leads to regression in fibrosis and parenchymal recovery ${ }^{[1]}$ Liver biopsy is important in the evaluation of patients with CLD. Besides establishing the diagnosis, it is often used to assess the severity of the disease in terms of both grade and stage for which many different validated scoring systems have been published. Chronic viral hepatitis has been the object of grading and staging, stimulated by the advent of new forms of therapy. Systems have also been developed for fatty liver disease, chronic cholestatic diseases and allograft rejection, but have not been widely used. ${ }^{[2]}$

Although many patients with liver disease possess one dominant pathological process, in some settings, coexistence of multiple etiologies play a significant role in disease progression. Some of the histologic features in various entities of differing etiologies may be similar, but it may be distinguishable by careful histopathologic examination for an accurate diagnosis. ${ }^{[3,4]}$
Advances in medical technology and drug therapy with refinements in surgical techniques, have greatly influenced the diagnosis and management of hepatic disease and as a consequence the role of liver biopsy is also evolving. ${ }^{[5]}$

This study was undertaken to study the histopathological pattern and assess the degree of injury, the staging of fibrosis in patients with CLD and to establish the possible etiologic diagnosis in correlation with clinical, histologic, biochemical and serologic findings.

\section{Material and Methods}

Thirty five cases of chronic liver disease with histopathological features of necroinflammation/fibrosis were studied for a period of five years from 2012 to 2016 . All liver biopsy specimens fixed in $10 \%$ formalin were routinely processed. Two widely separated sections were prepared and stained with hematoxylin and eosin (H\&E). A panel of special stains were applied to the intervening sections including, Periodic acid schiff with and without Diastase (PAS and PAS-D), Masson's trichome (MTS), Reticulin, Verhoeff-Van Gieson (VVG), Perls stain and Orcein stain. MTS was used for the evaluation of type I 
collagen and therefore to determine the increased amount of collagen as well as fibrosis. Type III collagen was highlighted by reticulin, while VVG and orcein stains were used to stain elastic fibres. PAS stain was helpful in evaluating bile duct basement membrane.

The demographics, hematological parameters, coagulation profile, liver function tests, viral serological markers, autoimmune profile including antinuclear antibody, anti smooth muscle antibody and anti mitochondrial antibody levels were recorded wherever available. Findings of upper gastro intestinal endoscopy and ultra-sonography of abdomen were noted wherever done. The Statistical analysis was performed using the software IBM SPSS (version 23.0).

\section{Results}

Demographic data: The age of patients ranged from 30 to 74 years with a mean of $52.4 \pm 11.93$ years. Majority of the patients were in the age group of 50-59 years. Nineteen $(54.29 \%)$ were females and $16(45.71 \%)$ were males with a male to female ratio of $0.84: 1$.

Clinical presentation: The common presenting symptom was abdominal pain (57.14\%), followed by jaundice and fever. Other symptoms were abdominal distension, vomiting, loss of appetite, hematemesis and generalized itching. Nine patients $(25.7 \%)$ had history of alcohol consumption. Eleven patients (31.4\%) had comorbidities like diabetes mellitus, hypertension, ischemic heart disease, rheumatoid arthritis, retroviral disease and hypothyroidism for which they were taking treatment. Hepatomegaly $(31.4 \%)$ was more common followed by splenomegaly $(14.2 \%)$ and some had both hepatosplenomegaly $(8.5 \%)$.

Liver function tests: were done in all the patients and the mean of all the values was calculated. Total bilirubin ranged from 0.3 to $27.4 \mathrm{mg} / \mathrm{dl}$ with a mean of $4.96 \pm 6.625$ $\mathrm{mg} / \mathrm{dl}$. Direct bilirubin ranged between 0.1 and $16.5 \mathrm{mg} /$ $\mathrm{dl}$ with a mean of $2.61 \pm 3.45 \mathrm{mg} / \mathrm{dl}$. AST, ALT and ALP values ranged between 18 to $910 \mathrm{IU} / \mathrm{L}, 10$ to $685 \mathrm{IU} / \mathrm{L}$ and 52 to $1500 \mathrm{IU} / \mathrm{L}$ with a mean of $110.05 \pm 146.10 \mathrm{IU} / \mathrm{L}, 80.8$ $\pm 112.73 \mathrm{IU} / \mathrm{L}$ and $375.42 \pm 302.41 \mathrm{IU} / \mathrm{L}$ respectively.

Tissue sections were studied for the pattern of injury, degree of injury, and staging of fibrosis. They were correlated with clinical findings, liver function tests, viral markers and autoimmune profile to establish the most likely etiological diagnosis.

Non alcoholic fatty liver disease (31.42\%) and alcoholic liver disease $(25.71 \%)$ were the most common causes followed by viral hepatitis $(8.57 \%)$ and drug induced liver injury. None of the cases were positive for hepatitis C. Significant histopathological features were seen in a single case of Hepatitis E. One case each of autoimmune hepatitis and PBC were seen. However in six patients, a definitive etiological diagnosis was not possible and only the probable etiology was considered. Orcein and Perls stain were used for copper associated proteins and iron respectively which was not significant in any cases.

Table 1: Comparison of etiologies of CLDs.

\begin{tabular}{|c|c|c|c|c|c|c|c|c|c|c|c|}
\hline & NASH & ALD & VH & DILI & PBC & $\begin{array}{c}\text { AMA } \\
\text { negative } \\
\text { PBC }\end{array}$ & AlH & $\begin{array}{c}\text { ANA } \\
\text { negative } \\
\text { AlH }\end{array}$ & GH & Cholestatic & Cryptogenic \\
\hline Giannousis IP et al ${ }^{15}$ & 9.2 & 4.8 & 86.0 & - & - & - & - & - & - & - & - \\
\hline Bell BP et al ${ }^{12}$ & 9.0 & 8.0 & - & - & - & - & - & - & - & - & - \\
\hline Michitaka $\mathrm{K}$ et al ${ }^{11}$ & 2.4 & 13.6 & 74.8 & - & 2.9 & - & 1.9 & - & - & - & - \\
\hline Fung $\mathrm{KT}$ et al ${ }^{16}$ & 1.5 & 1.7 & 94.5 & - & 1.3 & - & 0.5 & - & - & - & 0.5 \\
\hline Nayak NC et al ${ }^{17}$ & 16.7 & 23.1 & 48.6 & - & 4.3 & - & 2.1 & - & - & - & 2.7 \\
\hline Sagnelli E et al ${ }^{13}$ & 6.3 & 6.4 & 17.2 & - & 1.1 & - & 2.3 & - & - & - & 6.3 \\
\hline Wang $X$ et $a^{14}$ & - & 5.6 & 80.6 & 0.1 & - & - & 2.0 & - & - & - & 2.93 \\
\hline Present study (n-35) & $\begin{array}{c}31.42 \\
(11)\end{array}$ & $\begin{array}{c}25.7 \\
(9)\end{array}$ & $\begin{array}{c}11.4 \\
(4)\end{array}$ & $\begin{array}{c}8.58 \\
(3)\end{array}$ & $\begin{array}{c}2.86 \\
(1)\end{array}$ & $\begin{array}{c}5.71 \\
(2)\end{array}$ & $\begin{array}{c}2.86 \\
(1)\end{array}$ & $\begin{array}{c}2.86 \\
(1)\end{array}$ & $\begin{array}{c}2.86 \\
(1)\end{array}$ & $\begin{array}{c}2.86 \\
(1)\end{array}$ & $\begin{array}{c}2.86 \\
(1)\end{array}$ \\
\hline
\end{tabular}


Table 2: Histological findings in NASH and ALD.

\begin{tabular}{|c|c|c|c|c|c|}
\hline \multirow[t]{2}{*}{ Histological findings } & \multicolumn{3}{|c|}{ NASH } & \multicolumn{2}{|c|}{ ALD } \\
\hline & Grading & No of cases & Percentage & No of cases & Percentage \\
\hline \multirow{4}{*}{ Steatosis } & Grade 0 & 0 & 00.00 & 1 & 22.22 \\
\hline & Grade 1 & 5 & 45.46 & 2 & 55.56 \\
\hline & Grade 2 & 4 & 36.36 & 5 & 11.11 \\
\hline & Grade 3 & 2 & 18.18 & 1 & 11.11 \\
\hline \multirow{4}{*}{ Lobular inflammation } & Absent & 2 & 63.64 & 0 & 0.00 \\
\hline & $1+$ & 7 & 18.18 & 3 & 33.33 \\
\hline & $2+$ & 2 & 18.18 & 3 & 33.33 \\
\hline & $3+$ & 0 & 00.00 & 3 & 33.33 \\
\hline \multirow{2}{*}{$\begin{array}{l}\text { Ballooning } \\
\text { degeneration }\end{array}$} & $1+$ & 10 & 90.90 & 4 & 44.44 \\
\hline & $2+$ & 1 & 9.10 & 5 & 55.56 \\
\hline \multirow{6}{*}{ Fibrosis } & $2 / 4$ & 2 & 18.18 & 0 & 00 \\
\hline & $3 / 4$ & 6 & 54.54 & 0 & 00 \\
\hline & $4 / 4$ & 3 & 27.28 & 0 & 00 \\
\hline & $5 / 6$ & $\mathrm{NA}$ & & 1 & 11.11 \\
\hline & $6 / 6$ & NA & & 8 & 88.89 \\
\hline & & 11 & & 09 & \\
\hline
\end{tabular}

Table 3: Laboratory findings and Histological features in various etiologies of CLD.

\begin{tabular}{|c|c|c|c|c|c|c|c|}
\hline $\begin{array}{l}\text { SI } \\
\text { No }\end{array}$ & $\begin{array}{l}\text { Age/ } \\
\text { Sex }\end{array}$ & Lab findings & $\begin{array}{l}\text { Inflammation } \\
\text { Interface/ Portal/ Lobular } \\
\text { Necrosis- confluent / } \\
\text { Spotty }\end{array}$ & $\begin{array}{l}\text { Bile duct } \\
\text { Injury/ } \\
\text { Proliferation/ } \\
\text { Cholestasis }\end{array}$ & $\begin{array}{l}\text { Necro } \\
\text { Inflammatory } \\
\text { Score }\end{array}$ & Fibrosis & Diagnosis \\
\hline \multirow[t]{4}{*}{1.} & \multirow[t]{4}{*}{$55 / \mathrm{M}$} & \multirow{4}{*}{$\begin{array}{l}\text { T Bil/ Dir- 4.8/ } \\
2.7\end{array}$} & Lobular $1+$ & Cholestasis + & \multirow[t]{4}{*}{7 of 18} & \multirow[t]{4}{*}{4 of 6} & \multirow{4}{*}{$\begin{array}{l}\text { Chronic } \\
\text { hepatitis with } \\
\text { DILI }\end{array}$} \\
\hline & & & Portal 3+ & BD Prol 1+ & & & \\
\hline & & & Interface 3+ & & & & \\
\hline & & & Spotty nec 1+ & & & & \\
\hline \multirow[t]{4}{*}{2} & \multirow[t]{4}{*}{$59 / \mathrm{M}$} & \multirow{4}{*}{$\begin{array}{l}\text { T Bil/ Dir- } \\
27.4 / 16.5 \text { ANA } \\
\text { neg }\end{array}$} & Lobular 1+ & Cholestasis + & \multirow[t]{4}{*}{5 of 18} & \multirow[t]{4}{*}{5 of 6} & \multirow{4}{*}{$\begin{array}{l}\text { Cholestatic } \\
\text { pattern injury }\end{array}$} \\
\hline & & & Portal 2+ & BD prol 2+ & & & \\
\hline & & & Interface 2+ & & & & \\
\hline & & & Spotty nec $1+$ & & & & \\
\hline \multirow[t]{5}{*}{3} & \multirow[t]{5}{*}{$55 / \mathrm{M}$} & \multirow{5}{*}{$\begin{array}{l}\text { T Bil/ Dir-7.1/4.5 } \\
\text { AMA neg ASMA } \\
\text {-neg ANA neg } \\
\text { Anti HEV + }\end{array}$} & Lobular 2+ & Cholestasis + & \multirow[t]{5}{*}{11 of 18} & \multirow[t]{5}{*}{5 of 6} & \multirow{5}{*}{$\begin{array}{l}\text { Chronic } \\
\text { hepatitis with } \\
\text { anti HEV }\end{array}$} \\
\hline & & & Portal 3+ & BD prol 2+ & & & \\
\hline & & & Interface 3+ & & & & \\
\hline & & & Confluent nec $1+$ & & & & \\
\hline & & & Spotty nec 2+ & & & & \\
\hline \multirow[t]{5}{*}{4} & \multirow[t]{5}{*}{$60 / \mathrm{M}$} & \multirow[t]{5}{*}{ T Bil/ Dir 4.5/2.7 } & Lobular 2+ & BD injury + & \multirow[t]{5}{*}{13 of 18} & \multirow[t]{5}{*}{2 of 6} & \multirow{5}{*}{$\begin{array}{l}\text { Chronic } \\
\text { hepatitis with } \\
\text { DILI }\end{array}$} \\
\hline & & & Portal 3+ & BD Prol 1+ & & & \\
\hline & & & Interface 3+ & & & & \\
\hline & & & Confluent nec 5+ & & & & \\
\hline & & & Spotty nec $2+$ & & & & \\
\hline \multirow[t]{4}{*}{5} & \multirow[t]{4}{*}{$50 / \mathrm{M}$} & \multirow{4}{*}{$\begin{array}{l}\text { T Bil/Dir- 1.9/1.1 } \\
\text { HBS Ag + }\end{array}$} & Lobular 1+ & Cholestasis + & \multirow[t]{4}{*}{10 of 18} & \multirow[t]{4}{*}{5 of 6} & \multirow{4}{*}{$\begin{array}{l}\text { Chronic } \\
\text { hepatitis B }\end{array}$} \\
\hline & & & Portal 3+ & BD Prol 1+ & & & \\
\hline & & & Interface 3+ & & & & \\
\hline & & & Spotty nec $2+$ & & & & \\
\hline
\end{tabular}




\begin{tabular}{|c|c|c|c|c|c|c|c|}
\hline $\begin{array}{l}\text { SI } \\
\text { No }\end{array}$ & $\begin{array}{l}\text { Agel } \\
\text { Sex }\end{array}$ & Lab findings & $\begin{array}{l}\text { Inflammation } \\
\text { Interface/ Portal/ Lobular } \\
\text { Necrosis- confluent / } \\
\text { Spotty }\end{array}$ & $\begin{array}{l}\text { Bile duct } \\
\text { Injury/ } \\
\text { Proliferation/ } \\
\text { Cholestasis }\end{array}$ & $\begin{array}{l}\text { Necro } \\
\text { Inflammatory } \\
\text { Score }\end{array}$ & Fibrosis & Diagnosis \\
\hline \multirow[t]{3}{*}{6} & \multirow[t]{3}{*}{$35 / F$} & \multirow{3}{*}{$\begin{array}{l}\text { T Bil/ Dir- } \\
\text { 1.5/0.9 AMA + } \\
\text { ASMA- ANA - }\end{array}$} & Lobular 2+ & BD injury + & \multirow[t]{3}{*}{-} & \multirow[t]{3}{*}{ absent } & \multirow[t]{3}{*}{ PBC Stage 2} \\
\hline & & & Portal 2+ & & & & \\
\hline & & & Interface 2+ & & & & \\
\hline \multirow[t]{4}{*}{7} & \multirow[t]{4}{*}{$64 / \mathrm{M}$} & \multirow{4}{*}{$\begin{array}{l}\text { T Bil/Dir- 1.1/0.7 } \\
\text { HBS Ag + }\end{array}$} & Portal 2+ & BD Prol 1+ & \multirow[t]{4}{*}{7 of 18} & \multirow[t]{4}{*}{2 of 6} & \multirow{4}{*}{$\begin{array}{l}\text { Chronic } \\
\text { hepatitis B }\end{array}$} \\
\hline & & & Interface 3+ & & & & \\
\hline & & & Confluent nec 2+ & & & & \\
\hline & & & Spotty nec $2+$ & & & & \\
\hline \multirow[t]{4}{*}{8} & \multirow[t]{4}{*}{$48 / \mathrm{F}$} & \multirow{4}{*}{$\begin{array}{l}\text { T Bil/ Dir- } \\
\text { 0.92/0.39 AMA- } \\
\text { ASMA- ANA- }\end{array}$} & Portal 3+ & \multirow[t]{4}{*}{ BD Prol 3+ } & \multirow[t]{4}{*}{15 of 18} & \multirow[t]{4}{*}{5 of 6} & \multirow[t]{4}{*}{ ANA neg $\mathrm{AlH}$} \\
\hline & & & Interface $3+$ & & & & \\
\hline & & & Confluent nec 5+ & & & & \\
\hline & & & Spotty nec $2+$ & & & & \\
\hline \multirow[t]{3}{*}{9} & \multirow[t]{3}{*}{$55 / F$} & \multirow{3}{*}{$\begin{array}{l}\text { T Bil/ Dir- } \\
\text { 5.5/2.6 AMA- } \\
\text { ASMA - ANA + }\end{array}$} & Lobular 1+ & BD injury + & \multirow[t]{3}{*}{-} & \multirow[t]{3}{*}{ bridg fib+ } & \multirow[t]{3}{*}{ AMA neg PBC } \\
\hline & & & Portal 2+ & BD prol 1+ & & & \\
\hline & & & Interface 3+ & & & & \\
\hline \multirow[t]{2}{*}{10} & \multirow[t]{2}{*}{$35 / F$} & T Bil/Dir- 2/0.9 & Portal 2+ & & - & Cirrhosis & Cryptogenic \\
\hline & & $\begin{array}{l}\text { AMA- ASMA - } \\
\text { ANA - }\end{array}$ & Interface 2+ & & & & \\
\hline 11 & $35 / F$ & T Bil/ Dir- & Lobular 1+ & Cholestasis + & 6 of 18 & 6 of 6 & Chronic hep \\
\hline & & 2.45/1.2 HIV + & Portal 2+ & BD Prol 3+ & & & with DILI \\
\hline & & & Interface 3+ & & & & \\
\hline & & & Spotty nec $1+$ & & & & \\
\hline 12 & $63 / F$ & T Bil/ Dir- & Lobular 1+ & Cholestasis + & - & cirrhosis & AMA neg PBC \\
\hline & & 7.6/5.5 AMA- & Portal 3+ & BD injury + & & & \\
\hline & & ASIVIA - ANA + & Interface 3+ & & & & \\
\hline 13 & $55 / F$ & T Bil/ Dir & Lobular 1+ & Cholestasis + & - & cirrhosis & Granulmatous \\
\hline & & -0.83/0.36 AMA- & Portal 2+, & BD Prol 1+ & & & hepatitis \\
\hline & & ASIVIA - AIVA + & Granuloma + & & & & \\
\hline & & & Interface 2+ & & & & \\
\hline 14 & $40 / F$ & & Lobular 1+ & & 3 of 18 & 2 of 6 & Chronic \\
\hline & & 0.3/0.14 HBS & Portal 1+ & & & & hepatitis B \\
\hline & & $\mathrm{Ag}+$ & Interface 1+ & & & & \\
\hline & & & Spotty necrosis 1+ & & & & \\
\hline 15 & $45 / F$ & T bil/Dir- 0.4/0.2 & Portal 2+ & & 8 of 18 & 3 of 6 & $\mathrm{AlH}$ \\
\hline & & AMA- ASMA - & Interface 1+ & & & & \\
\hline & & ANA + & Confluent nec 3+ & & & & \\
\hline & & & Spotty nec 2+ & & & & \\
\hline
\end{tabular}




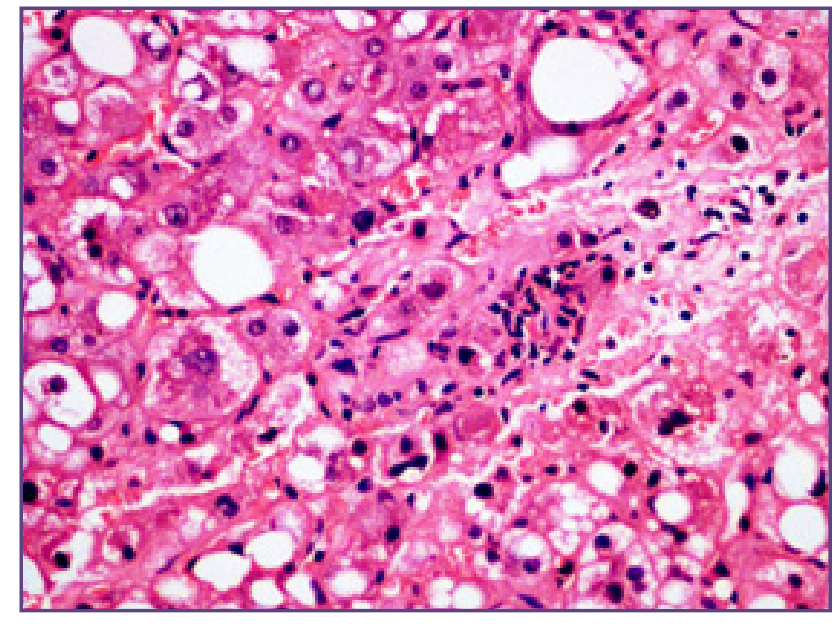

Fig. 1: Steatosis, glycogenated nuclei, Mallory Denk bodies and lobular inflammation in NASH.

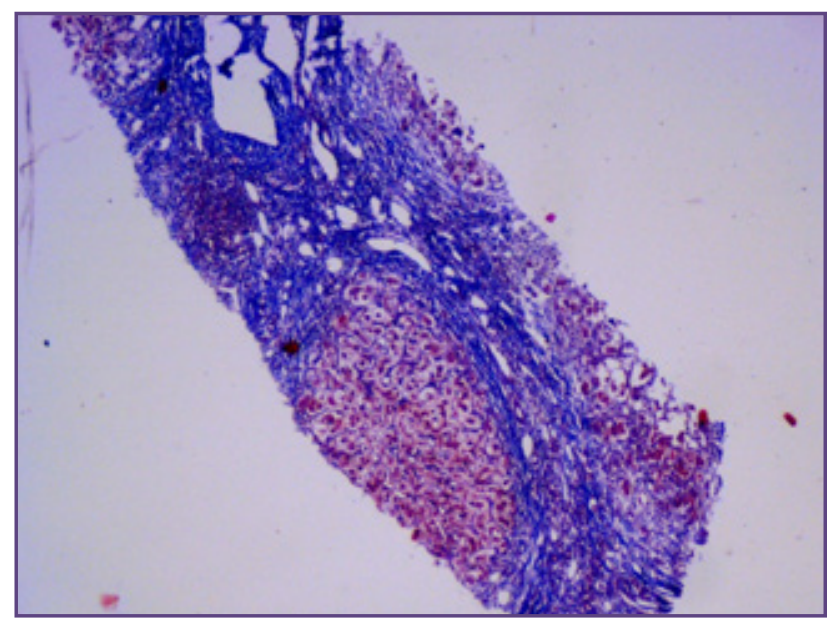

Fig. 3: Cirrhotic stage of fibrosis (stage 4) in PBC (MTS, $\mathrm{x40) \text {. }}$

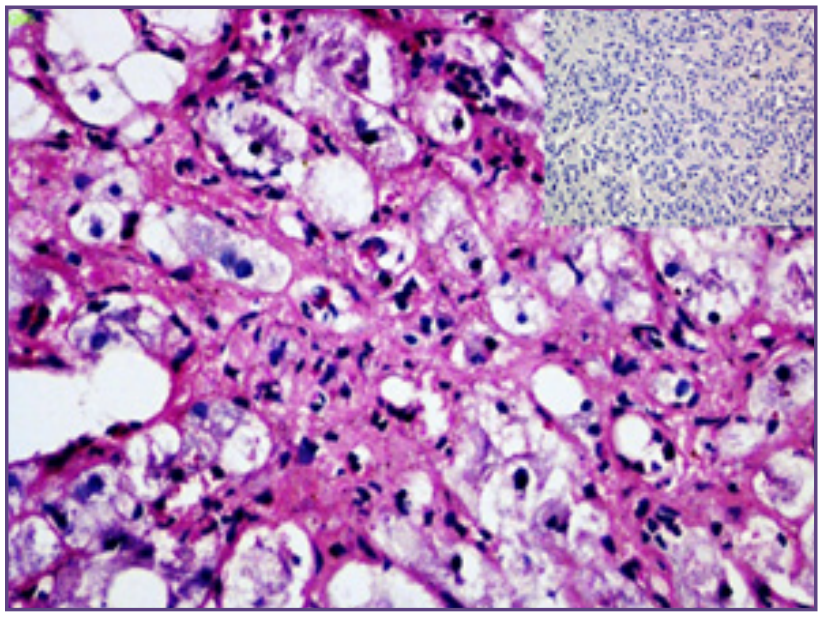

Fig. 2: Lobular inflammation, ballooning degeneration and necrosis in ALD(H\&E, x200).(Inset- Dysplastic cells arranged in acinar and trabecular patterns in ALD).

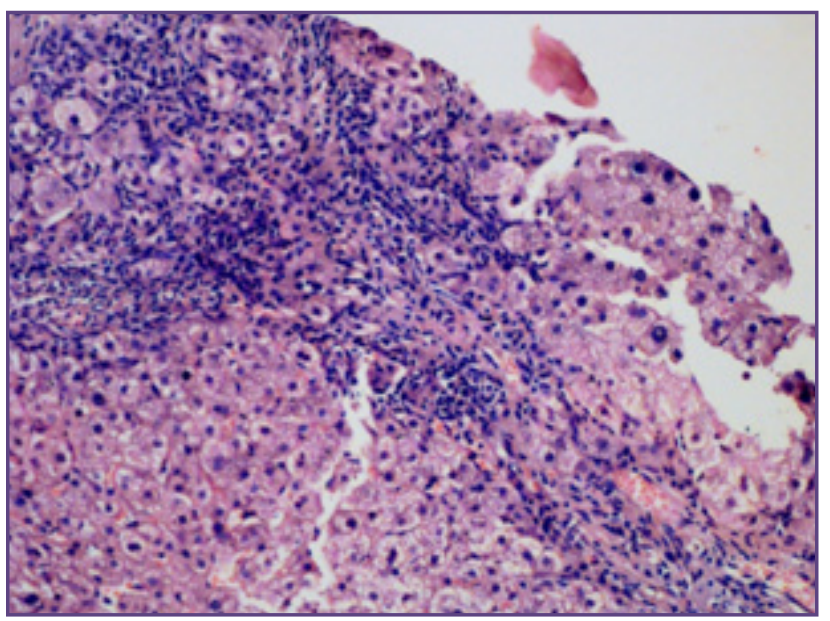

Fig 4: Moderate to severe portal inflammation with interface hepatitis in chronic hepatitis with DILI (H\&E, x100).

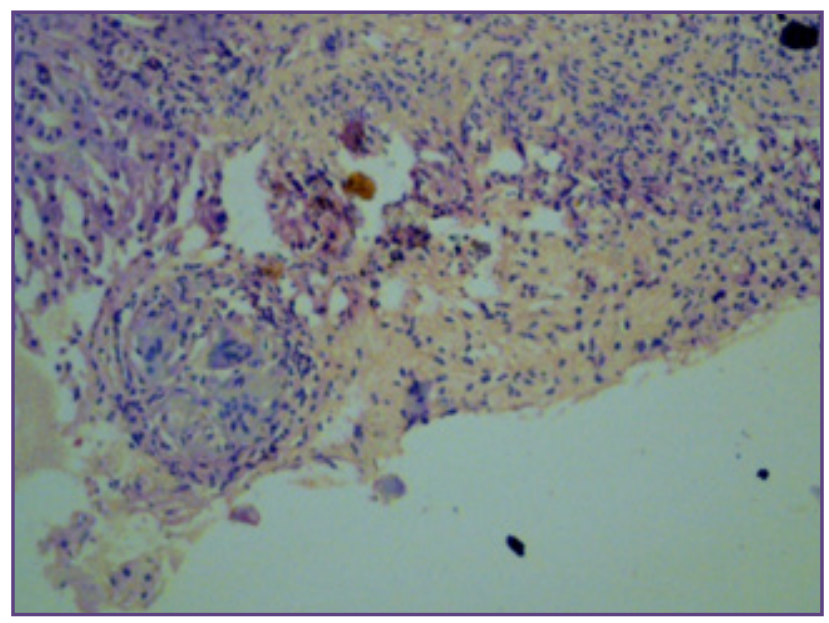

Fig. 5: Multiple epithelioid granulomas with giant cells in granulomatous hepatitis (H\&E, x100). 


\section{Discussion}

The epidemiology and natural history of chronic liver diseases (CLD) is now changing worldwide. The asymptomatic nature with slow progression to fibrosis may impede the early evaluation of these patients. ${ }^{[6]}$ Regardless of the etiology, most CLDs progress, in a variable interval of time, to a stage defined 'cirrhotic', in which the disease becomes clinically significant. ${ }^{[7]}$ Hence, it is crucial, to perform studies periodically to define the etiology and for staging which are important factors to determine the prognosis and treatment of CLD. ${ }^{[2,6]}$

In the present study, non-alcoholic steatohepatitis (NASH) $(31.42 \%)$ was the most common cause of CLD with occurrence in $81.8 \%$ females, followed by alcoholic liver disease (ALD) (25.71\%) seen only in males (100\%). ${ }^{[8,9,10]}$ The gender variation indicate that alcohol induced cirrhosis is predominant among males, whereas HCV, autoimmune hepatitis, primary biliary cirrhosis and NASH are predominant among females. ${ }^{[11]}$ It may be due to socioeconomic factors with alcohol abuse being more common in males. The duration of alcohol consumption ranged from 5 years to 15 years. Viral hepatitis was most prevalent in many studies. ${ }^{[11-17]}$ The data from a multicenter nationwide survey of 2557 CLD patients in Italy, has shown a steady decline of Hepatitis B, decreased impact of $\mathrm{HCV}$ and alcohol..$^{[13]}$ In the present study, there were 3 cases of Hepatitis B and one case of Hepatitis E.

The final etiology in a study of liver explants in 372 adult patients with CLD, in one of the largest orthotopic liver transplant centers in India have noted a change in the etiology of CLD over time. $\mathrm{HCV}$ is more common than HBV with a significant increase in NAFLD and alcohol induced CLD. AIH and PBC are infrequently diagnosed and seem to have a marginal role in the setting of CLD. ${ }^{[13,17]}$

NAFLD is recognized as one of the most common causes of CLD in western countries. ${ }^{[18]}$ In one of the Indian studies on 84 explant livers, a pre-operative diagnosis of cryptogenic cirrhosis were finally categorized as NAFLD in $65.5 \%$ of the cases and it is emerging as a common cause of CLD in Indian subcontinent. ${ }^{[17]}$ It is considered as liver manifestation of insulin resistance and metabolic syndrome, which may be attributed to sedentary lifestyles and comorbidities like diabetes mellitus. ${ }^{[13]}$ Of the 11 patients, 4 (36.3\%) had diabetes mellitus. Type 2 DM and NAFLD are at an increased risk of developing more aggressive liver disease and is considered as one of the strong independent predictors of disease progression. ${ }^{[10,19,20]}$

Premenopausal women are protected from having advanced fibrosis compared to men due to the estrogen effects although this protective effect is eliminated in post menopausal women. ${ }^{[21]}$ In the present study, most of the patients were postmenopausal females who had advanced fibrosis. Female gender is an independent risk factor for severity of fibrosis and increased levels of leptin, a proinflammatory cytokine are consistently reported in these patients. ${ }^{[19]}$ The regression of steatosis, hepatocyte ballooning, lobular inflammation has been observed with progression of fibrosis. Other features seen were mild to moderate portal inflammation and interface hepatitis in all the cases, presence of glycogenated nuclei $(27.2 \%)$, bile ductular proliferation (63.6\%), and Mallory hyaline/ MDBs (9\%). ${ }^{[8,10,18,19]}[$ Fig- 1]

\section{Alcoholic liver disease (ALD)}

Alcoholic liver disease represents a major cause of liver disease worldwide which may take the form of acute involvement (alcoholic hepatitis) or chronic liver disease (steatosis, steatohepatitis, fibrosis and cirrhosis). Their progression depends on the pattern of alcohol intake. ${ }^{[22]} \mathrm{In}$ the present study, the mean age of patients in NASH and ASH was $58.45 \pm 13.78$ years and $48.56 \pm 10.53$ years respectively. There might be reluctance for performing a liver biopsy for diagnosis until significant morbidity is present and therefore the age of presentation may be high. ${ }^{[8]}$

Grading and staging for ALD was done according to scoring system proposed by Yip and Burt in 2006. ${ }^{[23]}$ There was steatosis of all grades, ballooning degeneration, and lobular inflammation. All the nine patients had fibrosis ranging from incomplete to definite cirrhosis which may be due to persistent and prolonged consumption of alcohol which resulted in progression of the disease. ${ }^{[24,25]}$ This may be useful in assessing prognosis, or comparing biopsies in clinical trials. ${ }^{[8,9,24,25]}$ The cellular oxidative-stress together with endotoxemia, act as catalyst for the progression of steatohepatitis into hepatic necrosis, fibrosis, and cirrhosis. ${ }^{[26]}$

Other histological findings observed were mild to moderate interface hepatitis, portal inflammation, Mallory Denk bodies, hepatocellular and bile ductular cholestasis. ${ }^{[8,9,25]}$ Portal inflammation is associated with clinical and histologic features of advanced disease. ${ }^{[25]}$ Another notable feature was bile ductular proliferation and this may be due to the repeated occurence of liver injury along with necrotizing and fibrotic changes. ${ }^{[8]}$ Ductular reaction is stated to be a driver for fibrogenesis and therefore might be an important additional pathway for progressive fibrosis in ALD ${ }^{[23]}$ Dysplastic change was observed in one case when the patient underwent subsequent biopsy for worsening symptoms and deranged liver functions. [Fig-2] There is an increased risk of hepatocellular carcinoma in association with ALD. ${ }^{[27]}$ 


\section{Viral Hepatitis}

Chronic hepatitis B (CHB) is more common in Asia and nearly 45 million people suffer from this infection. ${ }^{[28]}$ However, overall prevalence of hepatitis B is decreased and is attributed to the effective vaccination programme and awareness about the possible modes of transmission. ${ }^{[13]}$ In the present study, there were three cases $(8.57 \%)$ of hepatitis B. The limited number of cases may be due to the inclusion of only the cases of CLD. The HBV DNA levels were 11 lakh copies in one case and 64 thousand copies in the other. A strong correlation between HBV DNA levels and liver damage is noted. ${ }^{[29,30,31]}$ However, low HBV-DNA levels do not exclude the presence of histologic disease. ${ }^{[31]}$ The quantitative measurement of intrahepatic HBV-DNA is a valuable marker of the histologic status of the liver in anti-HBe positive patients. ${ }^{[32]}$ However the quantification of intrahepatic HBV DNA was not done in the present study.

The grading and staging were done using modified histological activity index, the Ishak score ${ }^{[28-34]}$ Confluent necrosis of any degree in hepatitis B implies specific clinical events requiring attention. ${ }^{[29]}$ The other features seen were steatosis, ballooning degeneration, bile ductular proliferation and cholestasis. ${ }^{[28]}$ All the scoring systems are almost equally effective for grading and staging, but the interaction between pathologists and hepatologists is important to obtain meaningful and reproducible results. $[33,34]$

Chronic hepatitis E infection, though rare, can occur in the setting of immunosuppression. ${ }^{[35]}$ Goyal $\mathrm{R}$ et al in their study of four patients with hepatitis $\mathrm{E}$ virus induced acute on chronic liver failure (ACLF) have stressed on effectiveness of ribavirin as a therapeutic agent for HEV induced ACLF. ${ }^{[36]}$ There was no past history to suggest CLD or immunosuppression.

Primary Biliary Cirrhosis (PBC): It is often considered as a model autoimmune disease because of its hallmark signature, the antimitochondrial antibody (AMA) found in $90 \%-95 \%$ of patients and specific bile duct pathology. Kakuda $\mathrm{Y}$ et al and Chan et al have reported AMA positivity in $77.2 \%$ and $75.9 \%$ of the patients respectively. ${ }^{[37,38]}$ In the present study, a female patient with generalized itching had alkaline phosphatase level of $1500 \mathrm{IU} / \mathrm{L}$ and positive antimitichondrial antibody (AMA). Histopathology showed stage 2 according to Ludwig scoring system. Bile stasis may not be appreciated until decompensated liver disease has occurred. The differential diagnosis includes a cholestatic drug reaction, biliary obstruction, sarcoidosis, AIH and PSC. The size of liver biopsy specimen is important as the probability of observing cholangitis and bile duct destruction increases with the number of portal tracts because of the typical patchy distribution of the lesions. ${ }^{[39]}$

Chan et al found the Japanese staging system to be more effective and have stressed about stating the degree of copper associated protein (CAP) deposition in the pathology report and is considered as an essential prognostic histologic parameter. ${ }^{[38]}$ Ursodeoxycholic acid (UDCA) is widely used for the treatment of PBC and has reduced the need for liver transplantation. ${ }^{[39]}$ Novel predictive markers like APRI (Aspartate Aminotransferase to Platelet Ratio Index) score have been studied to identify PBC patients with unfavourable outcome. ${ }^{[40]}$

Two female patients negative for AMA had positive ANA and elevated alkaline phosphatase levels with histopathological features suggestive of PBC. AMAnegative PBC lack AMA but have clinical findings, liver histology, and natural history nearly identical to patients with typical AMA-positive PBC. However, minimal differences in histopathology, immunology, and human leukocyte antigen status exist between them. Nearly all of these patients have antinuclear and/or anti-smooth muscle antibodies. Mitochondrial antigen is expressed on the apical membranes of biliary epithelial cells in both AMA-negative as well as AMA-positive PBC, suggesting that their pathogenesis is similar. The diagnosis of AMAnegative $\mathrm{PBC}$ requires a liver biopsy that demonstrates the typical features of bile duct destruction seen in PBC. ${ }^{[39]}$ Liver biopsy in both the cases showed interface hepatitis, moderate to severe portal inflammation, bile duct injury, mild lobular inflammation, cholestasis and fibrosis with Ludwig stage 3 and 4 respectively. [Fig-3] They were categorized as AMA negative with histopathology suggestive of $\mathrm{PBC} \cdot{ }^{[39]}$ Chan $\mathrm{AW}$ et al have reported AMA negative $\mathrm{PBC}$ in $24.1 \%$ in their cohort study of 52 patients with $\mathrm{PBC}$ and they state that AMA negative PBC is common in Asian population. There are no significant differences observed in respect to clinical, biochemical pathological and clinical outcomes when compared to AMA positive PBC patients. A less significant chronic cholangitis activity is seen in AMA negative PBC patients. ${ }^{[38]}$

Autoimmune hepatitis (AIH), results from dysregulated immune mechanism and as per AASLD, the criteria for diagnosis of AIH include, compatible clinical signs and symptoms, laboratory abnormalities (serum AST or ALT and increased serum total $\mathrm{IgG}$ ), serological (ANA,SMA, anti-LKM 1, or anti-LC1), and histological findings, exclusion of other conditions that can cause chronic hepatitis, including viral, hereditary, metabolic, cholestatic, and drug-induced diseases. ${ }^{[41,42]}$ In the present 
study, a female patient positive for antinuclear antibody (ANA) and negative for viral serological markers showed necroinflammation and fibrosis with score of $8 / 18$ and $3 / 6$ respectively (Ishak grade) ${ }^{[43,44]}$ Emperipolesis and rosette formation, considered as superior histological predictors of $\mathrm{AIH}$, however were not seen ${ }^{[43]}$ Emperipolesis is associated with severe inflammatory activity as reflected by elevated transaminase levels and more advanced necroinflammatory grade. It is predominantly mediated by CD8 $\mathrm{T}$ (Cluster differentiation) cells which appears to induce apoptosis, might be another mechanism for autoimmune mediated hepatocyte injury. ${ }^{[45]}$ Hyaline droplets in Kupffer cells, provide a useful diagnostic clue to distinguish AIH from other forms of chronic hepatitis. ${ }^{[46]}$

Another female patient who presented with history of vomiting, pain abdomen was found to have normal liver functions, negative viral, serological markers and autoimmune markers. The necroinflammatory score of $15 / 18$ with fibrosis score of $5 / 6$ along with liver cell rosettes, emperipolesis and bile duct proliferation favoured a diagnosis of ANA negative AIH. Mehendiratta $\mathrm{V}$ et al in their study of 52 patients with AIH noted $19 \%$ of patients to be serologically negative for ANA and ASMA. These patients were included in the study on the basis of revised scoring system of International Autoimmune Hepatitis group. They concluded that prevalence of ANA or ASMA did not correlate with clinical or histological severity. They also noted that there was no correlation between antibody status and response to immunosuppressive therapy and they have recommended that these patients should be given immunosuppressive therapy. ${ }^{[44]}$

Drug induced liver injury (DILI) DILI is an important cause of liver disease with significant mortality and morbidity ${ }^{[47]}$ Evaluation of liver biopsy for adverse drug reactions is very challenging in liver pathology. ${ }^{[48]}$ The likliehood of DILI as the reason for liver injury is considered definite in $32 \%$, highly likely in $41 \%$, probable in $14 \%$ and possible in $10 \%_{{ }_{[49]}}$ The most common histological patterns are acute hepatitis $(21 \%)$, chronic hepatitis (14\%), acute cholestasis $(9 \%)$, chronic cholestasis $(10 \%)$ and cholestatic hepatitis. ${ }^{[47]}$

In the present study, there were three cases of chronic hepatitis with deranged liver function tests but workup of these patients did not suggest a definite etiology. The biochemical patterns of injury were documented based on $\mathrm{R}$ Ratio. The history revealed the presence of co-morbidities namely rheumatoid arthritis, human immunodeficiency virus infection, hypertension for which they were on methotrexate, anti-retroviral therapy and ACE inhibitors with native medicines respectively. Histological features were suggestive of chronic hepatocellular pattern of injury, chronic hepatitis with 6/6 fibrosis (complete cirrhosis) and chronic cholestatic pattern of injury respectively. [Fig-4] Methotrexate causes non immune mediated hepatitis pattern of injury, steatosis and hepatocellular anisonucleosis. ART causes non immune mediated hepatitis pattern of injury. ${ }^{[48,50]}$ ACE inhibitors cause chronic cholestatic pattern of injury. ${ }^{[50]}$ Liver histology is considered helpful in strengthening the diagnosis or exclude other potential causes of liver injury.

Though an overlap of histologic findings exists for AIH and DILI, there are sufficient differences pathologically. The chronic hepatitic pattern, interface hepatitis and portal inflammation are present in both. The intra-acinar lymphocytes and canalicular cholestasis favour DILI while rosette formation, portal plasma cells, relatively severe portal inflammation, and prominent intra-acinar eosinophils favour AIH. ${ }^{[51]}$ In the present study, histological features were observed and Ishak score was documented. The outcome was not known as the patients were lost for follow up.

Others: The exact etiology could not be determined with the available data in three cases which include chronic intrahepatic cholestatic liver disease with bridging fibrosis, idiopathic/ cryptogenic cirrhosis and granulomatous hepatitis with cirrhosis. The common causes for intrahepatic cholestatic liver disease are $\mathrm{PBC}$, primary sclerosing cholangitis (PSC), AIH, ALD, viral hepatitis B and hepatitis C. ${ }^{[52]}$ NAFLD is the most common cause of cryptogenic cirrhosis. ${ }^{[33]}$ However, there were no features to suggest NAFLD. A complete workup of the patient and exclusion of all other causes is essential to diagnose cryptogenic cirrhosis. ${ }^{[54]}$ The diagnoses for hepatic granulomas include $\mathrm{PBC}$, sarcoidosis, idiopathic, hepatitis $\mathrm{C}$ virus, drug induced, $\mathrm{PBC} / \mathrm{AIH}$ overlap syndrome, $\mathrm{AIH}$ and tuberculosis. ${ }^{[55]}$ A diabetic with ischemic heart disease had portal hypertension and esophageal varices. ANA was positive with negative viral markers. Histopathology showed interface hepatitis, moderate portal inflammation, cholestasis, and bile ductular proliferation, epithelioid granulomas within lobules and portal triads and bridging fibrosis with nodules suggestive of cirrhosis [Fig-5]. A definite etiological diagnosis was not possible.

\section{Conclusion}

The epidemiology and natural history of CLD is changing worldwide. It is important to establish an etiological diagnosis to plan the treatment strategy and assess the prognosis. Although histopathology plays a key role in establishing the etiological diagnosis, it remains challenging 
and hence should be interpreted in the setting of clinical, biochemical, serological and radiological findings.

In the present study, an attempt is made to determine the etiology of chronic liver diseases. NASH and its association with co-morbidities like diabetes mellitus are gaining importance in progression of the disease. ALD still continues to be an important etiological factor in developing cirrhosis. Viral hepatitis, autoimmune hepatitis, drug induced liver injury were studied with emphasis on grading and staging using modified histological activity index, the Ishak score. Cases of DILI, AIH, PBC and granulomatous hepatitis posed a diagnostic difficulty to determine the etiology due to the absence of characteristic histologic features, presence of overlapping features and ambiguous serologic and biochemical findings. The traditional descriptive report of liver biopsies is still important in such cases to determine the treatment and the prognosis. Studies with larger sample size are necessary to know the prevalence of etiologies for CLD and also to understand the histological features of different etiologies.

\section{Acknowledgment}

We thank Mr Vasanth Kumar for the technical assistance

\section{Declaration}

Funding: None; Competing interests: None

\section{References}

1. Quaglia A, Alves VA, Balabaud C, Bhathal PS, Bioulac-Sage P, Crawford JM et al. Role of aetiology in the progression, regression and parenchymal remodelling of liver disease: implications for liver biopsy interpretation. Histopathology. 2016;68(7):953-67.

2. Goodman ZD. Grading and staging systems for inflammation and fibrosis in chronic liver diseases. J Hepatol. 2007;47(4):598-607.

3. Bateman AC. Patterns of histological change in liver disease: my approach to 'medical' liver biopsy reporting. Histopathology 2007;51(5):585-96.

4. Brunt EM, Ramrakhaini S, Cordes BG, Neuschwander-Tetri BA, Janney CG, Bacon BR et al. Concurrence of histologic features of steatohepatitis with other forms of chronic liver diseases. Mod Pathol. 2003;16(1):49-56.

5. Rockey DC, Caldwell SH, Goodman ZD, Nelson RC, Smith AD. Liver Biopsy. Hepatology. 2009;49(3):1017-44.

6. Saracco GM, Evangelista A, Fagoonee S, Ciccone G, Bugianesi E, Caviglia GP et al. Etiology of chronic liver diseases in the Northwest of Italy, 1998 through 2014. World J Gastroenterol. 2016;22(36):8187-93.

7. Pinzani M, Romanelli RG, Magli S. Progression of fibrosis in chronic liver diseases: time to tally score. Journal of Hepatology 2001; 34: 764-767.
8. Singh DK, Rastogi A, Sakhuja P, Gondal R, Sarin SK. Comparison of clinical, biochemical and histological features of alcoholic steatohepatitis and non alcoholic steatohepatitis in Asian Indian patients. Indian J Pathol Microbiol. 2010;53(3):408-413.

9. Kazemi-Shirazi L, Veloso MP, Frommlet F, Steindl-Munda P, Wrba F, Zehetmayer S et al. Differentiation of non alcoholic from alcoholic steatohepatitis: are routine laboratory markers useful?. Wien Klin Wochenschr. 2008;120(1-2):25-30.

10. Adams A, Sanderson S, Lindor KD, Angulo P. The histological course of non alcoholic fatty liver disease: a longitudinal study of 103 patients with sequential liver biopsies. J Hepatol. 2005;42:132-138.

11. Michitaka K, Nishiguchi S, Aoyagi Y, Hiasa Y, Tokumoto Y, Onji M; Japan Etiology of Liver Cirrhosis Study Group. Etiology of liver cirrhosis in Japan: a nation wide survey. J Gastroenterol. 2010;45(1):86-94.

12. Bell BP, Manos MM, Zaman A, Terrault N, Thomas A, Navarro VJ et al. The epidemiology of newly diagnosed chronic liver diseases in gastroenterology practices in the United States: results from population-based surveillance. Am J Gastroenterol. 2008;103(11):2727-36.

13. Sagnelli E, Stroffolini T, Sagnelli C, Smidile A, Morisco $\mathrm{F}$, Furlan $\mathrm{C}$ et al. epidemiological and clinical scenario of chronic liver diseases in Italy: Data from a multicenter nationwide survey. Dig Liver Dis. 2016;48(9):1066-71.

14. Wang X, Lin SX, Tao J, Wei XQ, Liu YT, Chen YM et al. Study of liver cirrhosis over ten consecutive years in Southern china. World J Gastroenterol. 2014;20(37):13546-55.

15. Giannousis IP, Papatheodoridis GV, Deutsch MJ, Manolakopoulos SG, Manesis EK, Koskinas JS et al. The burden and recent epidemiological changes of the main chronic liver diseases in the Greek referral tertiary center. Eur J Gastroenterol Hepatol. 2010;22(2):172-9.

16. Fung KT, Fung J, Lai CL, Yuen MF. Etiologies of chronic liver diseases in Hong Kong. Eur J Gastroenterol Hepatol. 2007;19(8):659-64.

17. Nayak NC, Jain D, Vasdev N, Gulwani H, Saigal S, Soin A. Etiologic types of end-stage chronic liver disease in adults: analysis of prevalence and their temporal changes from a study on native liver explants. Eur J Gastroenterol Hepatol. 2012;24(10):1199-208.

18. Kim YS, Jung ES, Hur W, Bae SH, Choi JY, Song MJ et al.Non invasive predictors of non alcoholicsteatohepatitis in Korean patients with histologically proven non alcoholic fatty liver disease.ClinMolHepatol. 2013;19(2):120-30.

19. Singh DK, Sakhuja P, Malhotra V, Gondal R, Sarin SK. Independent predictors of steatohepatitis and fibrosis in Asian Indian patients with non-alcoholic steatohepatitis. Dig Dis Sci. 2008;53(7):1967-76.

20. Ekstedt M, Hagström H, Nasr P, Fredrikson M, Stål P, Kechagias $\mathrm{S}$ et al. Fibrosis stage is the strongest predictor 
for disease-specific mortality in NAFLD after upto 33 years follow-up. Hepatology. 2015;61(5):1547-54.

21. Yang JD, Abdelmalek MF, Pang H, Guy CD, Smith AD, Diehl AM et al. Gender and menopause impact severity of fibrosis among patients with non alcoholic steatohepatitis. Hepatology. 2014;59(4):1406-14.

22. Bruha R, Dvorak K, Petrtyl J. Alcoholic liver disease. World J Hepatol. 2012;4(3):81-90.

23. Yip WW, Burt AD. Alcoholic liver disease. Semin Diagn Pathol. 2006;23(3-4):149-160.

24. Sakhuja P. Pathology of alcoholic liver disease, can it be differentiated from non alcoholic steatohepatitis?. World J Gastroenterol. 2014;20(44):16474-16479.

25. Rakha EA, Adamson L, Bell E, Neal K, Ryder SD, Kaye $\mathrm{PV}$ et al. Portal inflammation is associated with advanced histological changes in alcoholic and non-alcoholic fatty liver disease. J Clin Pathol. 2010 ;63(9):790-5.

26. Testino G, Burra P, Bonino F, Piani F, Sumberaz A, Peressutti $\mathrm{R}$ et al. acute alcoholic hepatitis, end stage alcoholic liver disease and liver transplantation: an Italian position statement. World J Gastroenterol. 2014;20(40):14642-51.

27. Sahlman P, Nissinen M, Pukkala E, Färkkilä M. Cancer incidence among alcoholic liver disease patients in Finland: A retrospective registry study during years 1996-2013. Int J Cancer. 2016;138(11):2616-21.

28. Rastogi A, Sakhuja P, Kumar A, Hissar S, Jain A, Gondal $\mathrm{R}$ et al. Steatosis in chronic hepatitis B: prevalence and correlation with biochemical, histologic, viral and metabolic parameters. Indian J Pathol Microbiol. 2011;54(3):454-9.

29. Shafaei S, Soleimani Amiri S, Hajiahmadi M, SadeghiHaddad-Zavareh M, Bayani M. Histological grading and staging of liver and its relation to viral loads in chronic anti-HBe positive hepatitis. Caspian $\mathrm{J}$ Intern Med. 2013;4(3):681-5.

30. Biazar T, Yahyapour Y, Hasanjani Roushan MR, Rajabnia R, Sadeghi M, Taheri $\mathrm{H}$ et al. Relationship between hepatitis B DNA viral load in the liver and its histology in patients with chronic hepatitis B. Caspian J Intern Med. 2015;6(4):209-12.

31. Nabuco LC, Villela-Nogueira CA, Perez RM, Ceci L, Pannain VL, Nogueira CM et al. HBV-DNA levels in HBsAg-positive blood donors and its relationship with liver histology. J Clin Gastroenterol. 2007;41(2):194-8.

32. Bayram A, Erkilic S, Ozkur A, Bayram M, Sari I. Quantification of intrahepatic total hepatitis B virus DNA in chronic hepatitis B patients and its relationship with liver histology. J Clin Pathol. 2008;61(3):338-42.

33. Mannan R, Misra V, Misra SP, Singh PA, Dwivedi M. A comparative evaluation of scoring systems for assessing necro-inflammatory activity and fibrosis in liver biopsies of patients with chronic viral hepatitis. J Clin Diagn Res. 2014;8(8):FC08-12.
34. Mohamadnejad M, Tavangar SM, Sotoudeh M, Kosari F, Khosravi M, Geramizadeh B et al. Histopathological Study of Chronic Hepatitis B: A Comparative Study of Ishak and METAVIR Scoring systems. Int J Organ Transplant Med. 2010;1(4):171-6.

35. Kumar S, Subhadra S, Singh B, Panda BK. Hepatitis E virus: the current scenario. Int J Infect Dis. 2013;17(4):e228-33.

36. Goyal R, Kumar A, Panda SK, Paul SB, Acharya SK. Ribavarin therapy for hepatitis $\mathrm{E}$ virus-induced acute on chronic liver failure: aprelimnary report. Antivir Ther. 2012;17(6):1091-6.

37. Kakuda Y, Harada K, Sawada-Kitamura S, Ikeda H, Sato Y, Sasaki $\mathrm{M}$ et al. evaluation of a new histologic staging and grading system for primary biliary cirrhosis in comparison with classical systems. Hum Pathol. 2013;44(6):1107-17.

38. Chan AW, Chan RC, Wong GL, Wong VW, Choi PC, Chan HL et al. Evaluation of histological staging systems for primary biliary cirrhosis: correlation with clinical and biochemical factors and significance of pathological parameters in prognostication. Histopathology. 2014;65(2):174-86.

39. Lindor KD, Gershwin ME, Poupon R, Kaplan M, Bergasa NV, Heathcote EJ; American Association for Study of Liver Diseases. Primary biliary cirrhosis. Hepatology. 2009;50(1):291-308.

40. Weinmann A, Sattler T, Unold HP, Grambihler A, Teufel A, Koch $\mathrm{S}$ et al. Predictive scores in primary biliary cirrhosis a retrospective single center analysis of 204 patients. J Clin Gastroenterol. 2015;49(5):438-47.

41. Joshi M, Khettry U. Approach to management of autoimmune hepatitis. Indian J Pathol Microbiol. 2009;52(3):297-303.

42. Manns MP, Czaja AJ, Gorham JD, Krawitt EL, MieliVergani G, Vergani D, Vierling JM; American Association for the Study of Liver Diseases. Diagnosis and management of autoimmune hepatitis. Hepatology. 2010;51(6):2193-213.

43. de Boer YS, van Nieuwkerk CM, Witte BI, Mulder CJ, Bouma G, Bloemena E. Assessment of the histopathological key features in autoimmune hepatitis. Histopathology. 2015;66(3):351-62.

44. Mehendiratta V, Mitroo P, Bombonati A, Navarro VJ, Rossi $\mathrm{S}$, Rubin R et al. Serologic markers do not predict histologic severity or response to treatment in patients with autoimmune hepatitis. Clin Gastroenterol Hepatol. 2009;7(1):98-103.

45. Miao Q, Bian Z, Tang R, Zhang H, Wang Q, Huang S et al. Emperipolesis mediated by CD8 $\mathrm{T}$ cells is a characteristic histopathologic feature of autoimmune hepatitis. Clin Rev Allergy Immunol. 2015;48(2-3):226-35.

46. Tucker SM, Jonas MM, Perez-Atayde AR. Hyaline droplets in Kupfer cells: A novel diagnostic clue for autoimmune hepatitis. Am J Surg Pathol. 2015;39(6):772-8.

47. Kleiner DE, Chalasani NP, Lee WM, Fontana RJ, Bonkovsky HL, Watkins PB et al. Hepatic histological findings in 
suspected drug-induced liver injury: systematic evaluation and clinical associations. Hepatology. 2014;59(2):661-70.

48. Ramachandran R, Kakar S. Histological patterns in druginduced liver disease. J Clin Pathol. 2009;62(6)481-92.

49. Chalasani N, Fontana RJ, Bonkovsky HL, Watkins PB, Davern T, Serrano J et al. Causes, clinical features, and outcomes from a prospective study of drug-induced liver injury in the United States. Gastroenterology. 2008;135(6):1924-34.

50. Abboud G, Kaplowitz N. Drug-induced liver injury. Drug Saf. 2007;30(4):277-94.

51. Suzuki A, Brunt EM, Kleiner DE, Miquel R, Smyrk TC, Andrade RJ et al. The use of liver biopsy evaluation in discrimination of idiopathic autoimmune hepatitis vs. druginduced liver injury. Hepatology. 2011;54(3):931-39.

52. Gossard AA, Talwalkar JA. Cholestatic liver disease. Med Clin North Am. 2014;98(1):73-85.

53. Clark JM, Diehl AM. Non alcoholic fatty liver disease: an underrecognized cause of cryptogenic cirrhosis. JAMA. 2003;289(22):3000-4.

54. Mercado-irizarry M, Torres EA. Crptogenic cirrhosis: current knowledge and future directions. Clinical liver disease. 2016;7(4):69-72.

55. Gaya DR, Thorburn D, Oien KA, Morris AJ, Stanley AJ. Hepatic granulomas: a 10 year single centre experience. J Clin Pathol. 2003;56(11):850-3.

*Corresponding author:

Dr Sheela Devi C S, Dept of Pathology, JSS Medical College, Mysuru, Karnataka, India

Phone: +919448390729

Email: devi.sheela1@gmail.com

Financial or other Competing Interests: None. 